In cooperation with the San Antonio Water System

Sources of Groundwater Based on Helium Analyses in and near the Freshwater/Saline-Water Transition Zone of the San Antonio Segment of the Edwvards Aquifier, South-Central Texas, 2002-03

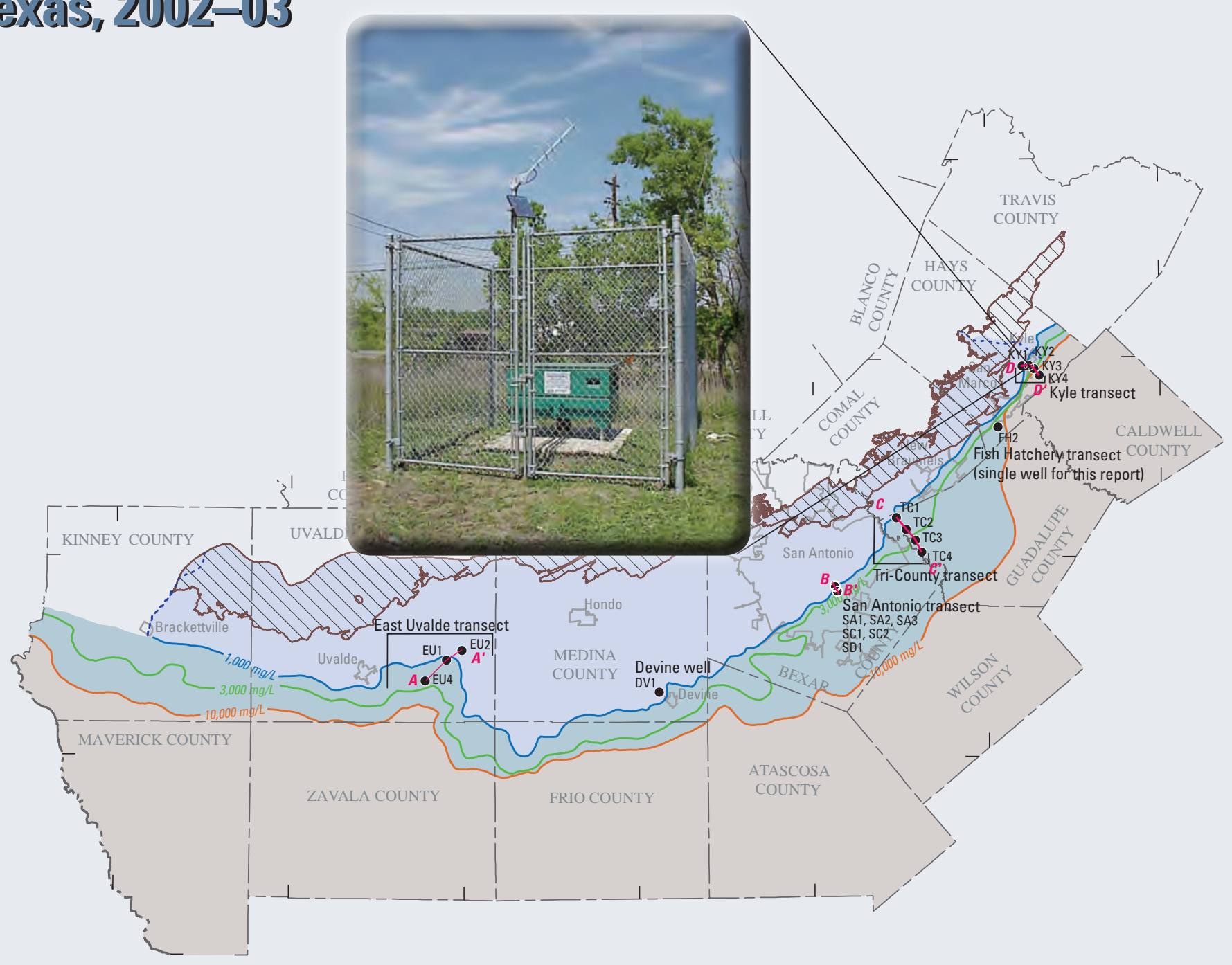

Scientific Investigations Report 2010-5030 
Front cover: Kyle 2 monitoring well, Hays County, Texas.

Back cover: Collecting sample with Kemmerer sampler. 


\section{Sources of Groundwater Based on Helium Analyses in and near the Freshwater/ Saline-Water Transition Zone of the San Antonio Segment of the Edwards Aquifer, South-Central Texas, 2002-03}

By Andrew G. Hunt, Rebecca B. Lambert, and Lynne Fahlquist

In cooperation with the San Antonio Water System

Scientific Investigations Report 2010-5030 


\section{U.S. Department of the Interior \\ KEN SALAZAR, Secretary \\ U.S. Geological Survey \\ Marcia K. McNutt, Director}

U.S. Geological Survey, Reston, Virginia: 2010

This and other USGS information products are available at http://store.usgs.gov/
U.S. Geological Survey
Box 25286 , Denver Federal Center
Denver, CO 80225
To learn about the USGS and its information products visit http://www.usgs.gov/
1-888-ASK-USGS

Any use of trade, product, or firm names is for descriptive purposes only and does not imply endorsement by the U.S. Government.

Although this report is in the public domain, permission must be secured from the individual copyright owners to reproduce any copyrighted materials contained within this report.

Suggested citation:

Hunt, A.G., Lambert, R.B., and Fahlquist, Lynne, 2010, Sources of groundwater based on helium analyses in and near the freshwater/saline-water transition zone of the San Antonio segment of the Edwards aquifer, south-central Texas, 2002-03: U.S. Geological Survey Scientific Investigations Report 2010-5030, 15 p. 


\section{Contents}

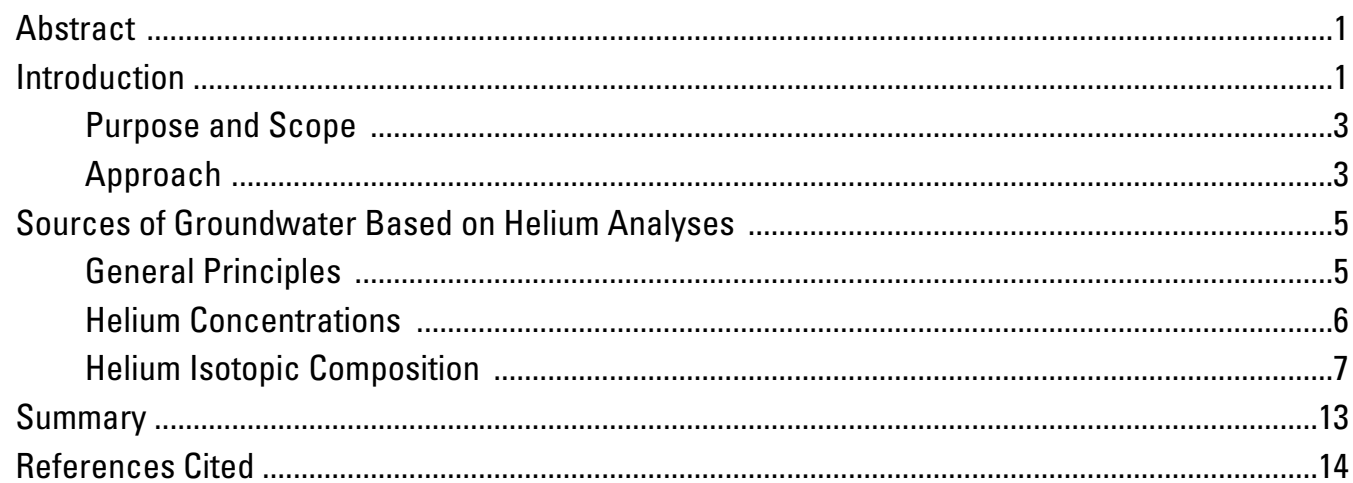

\section{Figures}

1. Map showing areal extent of freshwater/saline-water transition zone of the San Antonio segment of the Edwards aquifer, south-central Texas, and location of monitoring wells from which dissolved gas data were collected in and near the transition zone, 2002-03

2. Diagrammatic section showing generalized relation between the Edwards and Trinity aquifers and underlying pre-Cretaceous rocks

3-5. Graphs showing:

3. Relation of helium-4 concentration to salinity (computed dissolved solids concentration) in monitoring wells in and near the freshwater/saline-water transition zone of the San Antonio segment of the Edwards aquifer, southcentral Texas, 2002-03

4. Relation of sampling depth to helium-4 concentration in monitoring wells in and near the freshwater/saline-water transition zone of the San Antonio segment of the Edwards aquifer, south-central Texas, 2002-03

5. Relation of isotopic composition of excess helium-4 $\left(\mathrm{R} / \mathrm{R}_{\mathrm{A}}{ }^{4} \mathrm{He}{ }_{\mathrm{ex}}\right)$ to excess helium-4 $\left({ }^{4} \mathrm{He}_{\mathrm{ex}}\right)$ concentration in monitoring wells in and near the freshwater/saline-water transition zone of the San Antonio segment of the Edwards aquifer, south-central Texas, 2002-03

\section{Tables}

1. Descriptive information for monitoring wells from which dissolved gas data were collected in and near the freshwater/saline-water transition zone of the San Antonio segment of the Edwards aquifer, south-central Texas, 2002-03

2. Results of analyses of samples for dissolved gases from monitoring wells in and near the freshwater/saline-water transition zone of the San Antonio segment of the Edwards aquifer, south-central Texas, 2002-03 


\section{Conversion Factors, Datums, and Water-Quality Units}

\section{Inch/Pound to SI}

\begin{tabular}{lll}
\hline Multiply & By & To obtain \\
\hline & Length & \\
\hline inch (in.) & 2.54 & centimeter $(\mathrm{cm})$ \\
foot (ft) & 0.3048 & meter $(\mathrm{m})$ \\
mile (mi) & 1.609 & kilometer $(\mathrm{km})$ \\
\hline
\end{tabular}

\section{SI to Inch/Pound}

\begin{tabular}{ccc}
\hline Multiply & By & To obtain \\
\hline & Length & \\
\hline kilometer $(\mathrm{km})$ & 0.6214 & mile (mi) \\
\hline & Volume & \\
\hline liter $(\mathrm{L})$ & 0.2642 & gallon (gal) \\
\hline
\end{tabular}

Temperature in degrees Celsius $\left({ }^{\circ} \mathrm{C}\right)$ may be converted to degrees Fahrenheit $\left({ }^{\circ} \mathrm{F}\right)$ as follows:

$$
{ }^{\circ} \mathrm{F}=\left(1.8 x^{\circ} \mathrm{C}\right)+32
$$

\section{Datums}

Vertical coordinate information is referenced to the North American Vertical Datum of 1988 (NAVD 88).

Horizontal coordinate information is referenced to the North American Datum of 1983 (NAD 83).

\section{Water-Quality Units}

Specific conductance is given in microsiemens per centimeter at $25^{\circ} \mathrm{C}(\mu \mathrm{S} / \mathrm{cm})$.

Concentrations of chemical constituents are given in milligrams per liter (mg/L).

Concentrations of dissolved gases in water are given in microcubic centimeters per kilogram at standard temperature $\left(20^{\circ} \mathrm{C}\right)$ and pressure $(1$ atmosphere) $(\mu \mathrm{ccSTP} / \mathrm{kg})$ and in cubic centimeters per kilogram at standard temperature $\left(20^{\circ} \mathrm{C}\right)$ and pressure $(1$ atmosphere) (ccSTP/ $\mathrm{kg})$.

Concentrations of uranium in soil are given in milligrams per kilogram $(\mathrm{mg} / \mathrm{kg})$. 


\title{
Sources of Groundwater Based on Helium Analyses in and near the Freshwater/Saline-Water Transition Zone of the San Antonio Segment of the Edwards Aquifer, South- Central Texas, 2002-03
}

\author{
By Andrew G. Hunt, Rebecca B. Lambert, and Lynne Fahlquist
}

\section{Abstract}

This report evaluates dissolved noble gas data, specifically helium-3 and helium-4, collected by the U.S. Geological Survey, in cooperation with the San Antonio Water System, during 2002-03. Helium analyses are used to provide insight into the sources of groundwater in the freshwater/saline-water transition zone of the San Antonio segment of the Edwards aquifer. Sixty-nine dissolved gas samples were collected from 19 monitoring wells (categorized as fresh, transitional, or saline on the basis of dissolved solids concentration in samples from the wells or from fluid-profile logging of the boreholes) arranged in five transects, with one exception, across the freshwater/saline-water interface (the 1,000-milligrams-perliter dissolved solids concentration threshold) of the Edwards aquifer. The concentration of helium-4 (the dominant isotope in atmospheric and terrigenic helium) in samples ranged from 63 microcubic centimeters per kilogram at standard temperature (20 degrees Celsius) and pressure (1 atmosphere) in a well in the East Uvalde transect to 160,587 microcubic centimeters per kilogram at standard temperature and pressure in a well in the Kyle transect. Helium-4 concentrations in the 10 saline wells generally increase from the western transects to the eastern transects. Increasing helium-4 concentrations from southwest to northeast in the transition zone, indicating increasing residence time of groundwater from southwest to northeast, is consistent with the longstanding conceptualization of the Edwards aquifer in which water recharges in the southwest, flows generally northeasterly (including in the transition zone, although more slowly than in the freshwater zone), and discharges at major springs in the northeast.

Excess helium-4 was greater than 1,000 percent for 60 of the 69 samples, indicating that terrigenic helium is largely present and that most of the excess helium- 4 comes from sources other than the atmosphere. The helium data of this report cannot be used to identify sources of groundwater in and near the transition zone of the Edwards aquifer in terms of specific geologic (stratigraphic) units or hydrogeologic units (aquifers or confining units). However, the data indicate that the source or sources of the helium, and thus the water in which the helium is dissolved, in the transition zone are mostly terrigenic in origin rather than atmospheric. Whether most helium in and near the transition zone of the Edwards aquifer originated either in rocks outside the transition zone and at depth or in the adjacent Trinity aquifer is uncertain; but most of the helium in the transition zone had to enter the transition zone from the Trinity aquifer because the Trinity aquifer is the hydrogeologic unit immediately beneath and laterally adjacent to the transition zone of the Edwards aquifer. Thus the helium data support a hypothesis of sufficient hydraulic connection between the Trinity and Edwards aquifers to allow movement of water from the Trinity aquifer to the transition zone of the Edwards aquifer.

\section{Introduction}

The San Antonio segment of the Edwards aquifer, hereinafter the Edwards aquifer, is the primary source of water supply in south-central Texas and one of the most permeable and productive carbonate aquifers in the United States. The Edwards aquifer is about 180 miles long from west to east and ranges from 5 to 40 miles wide from north to south (Maclay, 1995) (fig. 1). The Edwards aquifer consists of regionally extensive, faulted and fractured carbonate rocks of the Georgetown Formation and Edwards Group that dip to the south and southeast. The less permeable and more clay-rich Trinity aquifer, composed primarily of Glen Rose Limestone, underlies and juxtaposes the Edwards aquifer to the north (Barker and Ardis, 1996, plate 3). To the west and east, the aquifer is bounded by groundwater divides and to the south and southeast by a zone of transition from freshwater to saline water.

The freshwater zone of the Edwards aquifer extends north to the northern limit of the aquifer, which coincides with the northern limit of the recharge zone (outcrop) of the aquifer 


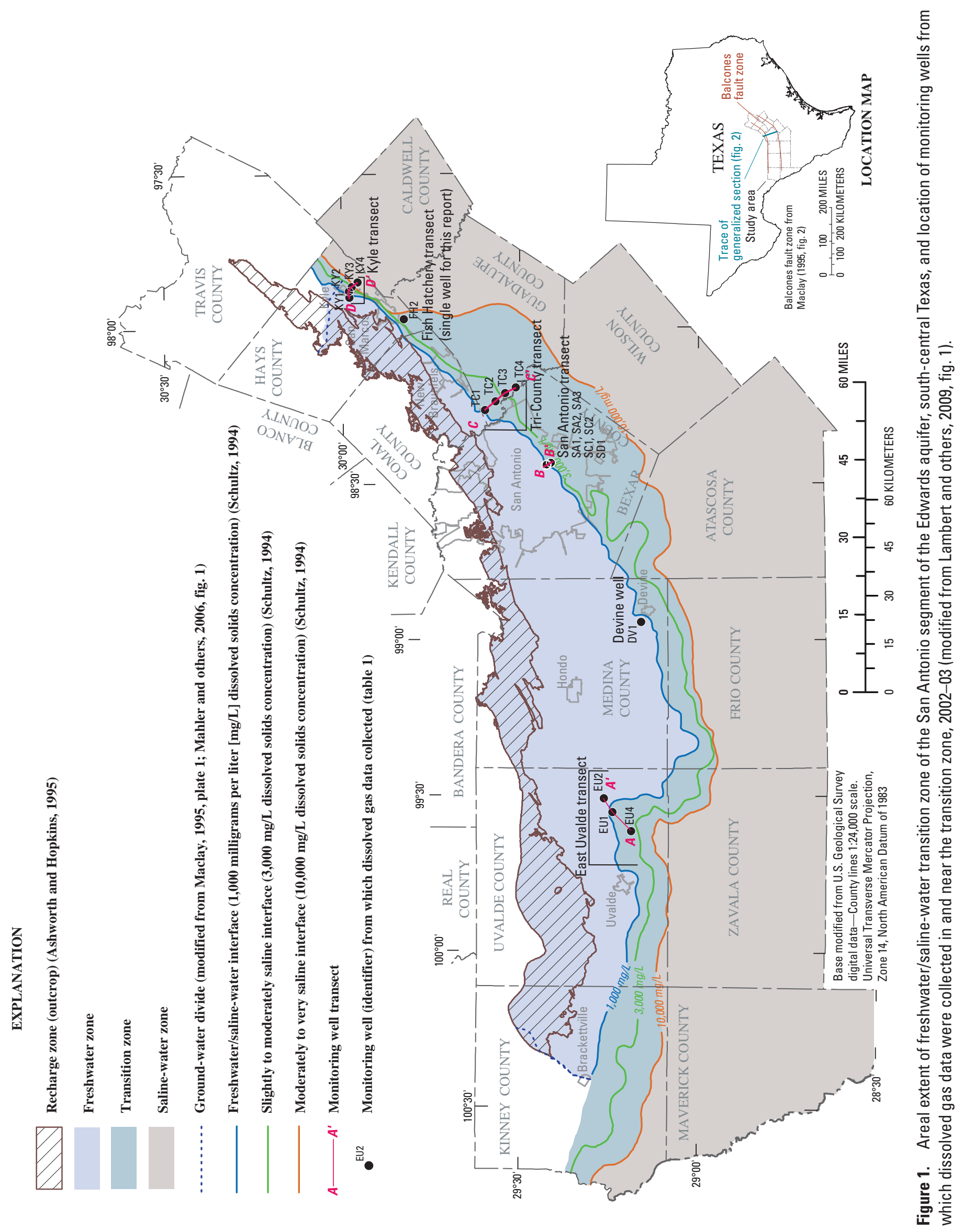


(fig. 1). Freshwater is defined as water with a dissolved solids concentration of 1,000 milligrams per liter $(\mathrm{mg} / \mathrm{L})$ or less; thus the freshwater/saline-water interface is the 1,000$\mathrm{mg} / \mathrm{L}$ dissolved solids concentration threshold. The transition zone of the aquifer is defined as the region with dissolved solids concentrations ranging from 1,000 to $10,000 \mathrm{mg} / \mathrm{L}$ (Schultz, 1994). Slightly saline water is defined as water with dissolved solids concentrations ranging from 1,000 to 3,000 $\mathrm{mg} / \mathrm{L}$; moderately saline is defined as water with dissolved solids concentrations ranging from 3,000 to $10,000 \mathrm{mg} / \mathrm{L}$; and very saline is defined as water with dissolved solids concentrations ranging from 10,000 to $35,000 \mathrm{mg} / \mathrm{L}$ (Winslow and Kister, 1956). On the basis of these definitions, the transition zone primarily contains water that is slightly or moderately saline, with very saline water in a few locations.

As the population increases throughout the region (U.S. Census Bureau, 2010), withdrawals from the aquifer likely will increase. Increased withdrawals lower water levels in the aquifer, which increases the potential for encroachment of saline water into the freshwater zone. In 1985, the U.S. Geological Survey (USGS), the San Antonio Water System (SAWS), and other Federal, State, and local agencies began a series of studies to learn more about the interaction between the freshwater and saline-water zones of the Edwards aquifer. The main goal of the studies was to provide better understanding of the potential for movement of saline water into the freshwater zone of the aquifer (Pavlicek and others, 1987; Poteet and others, 1992; Groschen and Buszka, 1997).

The objective of a more recent 9-year (1999-2007) study, done by the USGS in cooperation with SAWS, was to improve understanding of the hydrogeologic, hydraulic, and chemical characteristics of the transition zone of the Edwards aquifer. The study included drilling of additional monitoring wells by SAWS to expand the hydrogeologic and geochemical monitoring network in the aquifer across the freshwater/saline-water transition zone throughout the region. Monitoring wells were drilled or re-completed in and near the transition zone in Uvalde County (East Uvalde transect, four wells), in Medina County (South Medina well and Devine well), in Bexar County (Pitluck transect, three wells; Mission transect, three wells; San Antonio transect, seven wells), in Comal and Guadalupe Counties (Tri-County transect, five wells; New Braunfels transect, six wells), and in Hays County (Fish Hatchery transect, two wells; San Marcos transect, five wells; Kyle transect, four wells) (Lambert and others, 2009, fig. 1). Dissolved constituent and noble (inert) gas data were collected during 2002-03 from 19 of the 41 monitoring wells to further characterize geochemical and hydrologic processes occurring in and near the freshwater/saline-water transition zone.

\section{Purpose and Scope}

This report evaluates dissolved noble gas data, specifically helium-3 $\left({ }^{3} \mathrm{He}\right)$ and helium-4 $\left({ }^{4} \mathrm{He}\right)$, collected by the
USGS during 2002-03 as part of the larger, 9-year study of the freshwater/saline-water transition zone of the Edwards aquifer. Helium analyses are used to provide insight into the sources of water in the transition zone. Sixty-nine dissolved gas samples were collected from 19 monitoring wells arranged in five transects, except for the Devine well, across the freshwater/ saline-water interface of the Edwards aquifer. Other chemical, hydrologic, and geophysical data collected for the larger study are presented in Lambert and others (2009).

\section{Approach}

Water-quality samples and water-quality monitoring data were collected from 19 monitoring wells in and near the freshwater/saline-water transition zone to characterize chemical properties and changes in chemical properties of water over time. The 19 monitoring wells are categorized as fresh, transitional, or saline on the basis of dissolved solids concentration in samples from the wells or from fluidprofile logging of the boreholes (Lambert and others, 2009). The wells were drilled during 1972-2001 by various Federal, State, and local agencies. Most of the wells were constructed with the casing extending from land surface downward into the upper 20 feet of the Edwards aquifer. The remaining vertical extent of each borehole was completed as open hole in the aquifer. Where possible, the open-hole section of each well was drilled through the entire thickness of the aquifer. Some wells do not penetrate the entire thickness because of depth limitations of the drilling rigs. The 19 wells, except the Devine well, are arranged in five transects across the freshwater/ saline-water interface; transects are distributed spatially from Uvalde County to Hays County (fig. 1). Three wells are in the East Uvalde transect $\left(A-A^{\prime}\right.$ in fig. 1$)$; the Devine well is alone; six wells are in the San Antonio transect $\left(B-B^{\prime}\right)$; four wells are in the Tri-County transect $\left(C-C^{\prime}\right)$; one well is in the Fish Hatchery transect; and four wells are in the Kyle transect $\left(D-D^{\prime}\right)$. Descriptive information for wells sampled for dissolved gases is listed in table 1 and in Lambert and others (2009).

Field-property measurement techniques, samplecollection procedures for inorganic and isotopic samples, and results are described in Lambert and others (2009). Field properties $(\mathrm{pH}$, specific conductance, water temperature, depth to water) and samples for dissolved gases were collected at each well. For non-flowing wells in which the borehole was accessible, samples were collected at discrete depths in the uncased borehole using a 6-liter, stainless steel Kemmerer sampling flask attached to a portable cable winch fitted with a digital depth counter. The distances between depth intervals in a borehole water column where discrete samples were collected were based on changes in specific conductance with depth obtained from fluid salinity profiles (Lambert and others, 2009). Fewer samples were collected in water columns of relatively stable specific conductance than in water columns where specific conductance changed appreciably. After being lowered to the selected sampling depth, the Kemmerer flask was closed by 


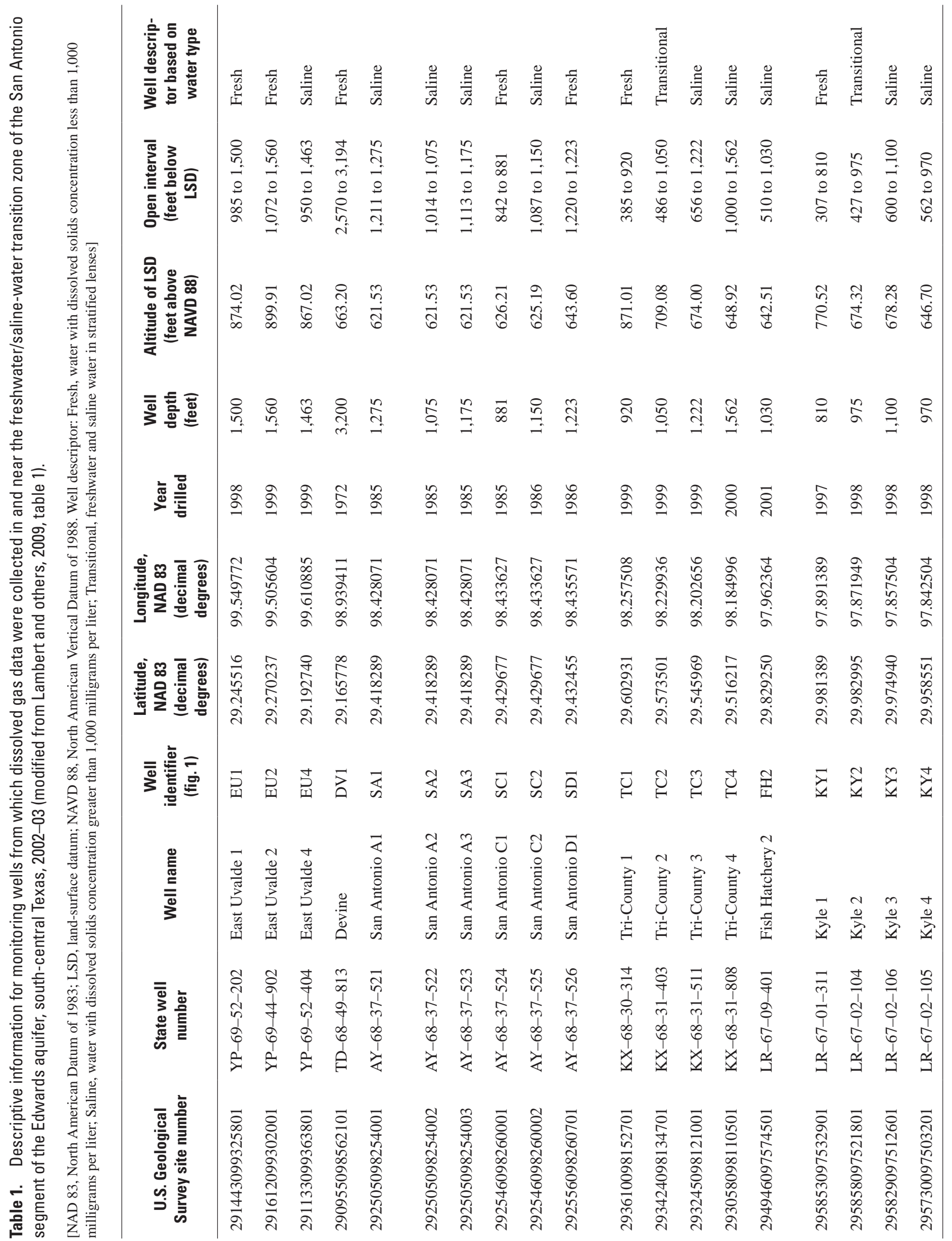


a sender weight and retrieved. For flowing wells in which the casing was accessible, a single composite sample was collected from a sampling spigot at the top of the casing after the well was purged and field properties had stabilized.

Dissolved gas samples were collected first to minimize atmospheric contamination; then the other inorganic and isotopic samples were collected. Dissolved gas samples were collected by connecting an approximately 1 -foot length of 0.375-inch-diameter copper tubing to Tygon tubing and allowing the water sample to flow from the Kemmerer sampler through the tubing. Once air bubbles were purged from the tubing, the copper tubing was crimped on both ends and sealed with refrigeration clamps. Care was taken to ensure that the samples were bubble-free and did not come into contact with the atmosphere.

Sixty-nine dissolved gas samples were analyzed for helium $(\mathrm{He})$, neon $(\mathrm{Ne})$, argon $(\mathrm{Ar})$, nitrogen $\left(\mathrm{N}_{2}\right)$, oxygen $\left(\mathrm{O}_{2}\right)$, and methane $\left(\mathrm{CH}_{4}\right)$ by the USGS Central Region Isotopic/Geochronology Core Operations Laboratory Support Project (Denver Noble Gas Laboratory) in Denver, Colo. Several wells were sampled at multiple depths. Isotopic ratios of ${ }^{3} \mathrm{He}$ to ${ }^{4} \mathrm{He}\left({ }^{3} \mathrm{He} /{ }^{4} \mathrm{He}\right)$, neon-20 to neon-22 $\left({ }^{20} \mathrm{Ne} /{ }^{22} \mathrm{Ne}\right)$, argon-40 to argon-36 $\left({ }^{40} \mathrm{Ar} /{ }^{36} \mathrm{Ar}\right)$, and nitrogen to argon concentration $\left(\mathrm{N}_{2} / \mathrm{Ar}\right)$ also were determined. ${ }^{3} \mathrm{He} /{ }^{4} \mathrm{He}$ in a sample (R), the isotopic composition, is commonly expressed as a multiple of ${ }^{3} \mathrm{He} /{ }^{4} \mathrm{He}$ in the atmosphere (in air) $\left(\mathrm{R}_{\mathrm{A}}\right)$. Dissolved gas samples were analyzed using procedures documented in Bayer and others (1989) and Solomon and others (1995). The dissolved gases were separated from the formation water in the laboratory and analyzed in an ultra-high vacuum extraction system. Total pressure of the extracted gases was measured on a capacitance manometer, and a split of the gas was run dynamically on a quadrapole mass spectrometer to obtain the concentrations of the major gas components $\left(\mathrm{CH}_{4}, \mathrm{~N}_{2}, \mathrm{Ar}, \mathrm{O}_{2}\right)$. The extracted gases then were separated using an STS-101 separator heated to 300 degrees Celsius, and another split of the gas was analyzed statically on a quadrapole mass spectrometer for isotopic measurements of $\mathrm{Ar}\left({ }^{36} \mathrm{Ar},{ }^{38} \mathrm{Ar}\right.$, and $\left.{ }^{40} \mathrm{Ar}\right)$. He and Ne were further separated from the sample gas using a cryogenic cold trap and then were analyzed for their isotopic composition $\left({ }^{3} \mathrm{He},{ }^{4} \mathrm{He},{ }^{20} \mathrm{Ne},{ }^{21} \mathrm{Ne}\right.$, and $\left.{ }^{22} \mathrm{Ne}\right)$ statically on a MAP-215-50 mass spectrometer. The $\mathrm{Ne}$ and $\mathrm{Ar}$ isotopic ratios are reported as absolute ratios, unlike the He isotope ratios expressed as $\mathrm{R} / \mathrm{R}_{\mathrm{A}}$.

No field quality-control dissolved gas samples were collected. For the Denver Noble Gas Laboratory, in-house quality-control standards were used to compute the percentage deviation from known values and to compute laboratory error for dissolved gas analyses. The in-house dissolved gas standards were cross-calibrated with air samples collected from Loveland Pass, Colo., and compared to known dissolved gas and bulk-gas compositions of U.S. Standard Atmosphere 1976 (Weast, 1983). Analytical variation (2-sigma standard deviation) of He gas analyses typically was 1 percent or less of that measured in the samples.

\section{Sources of Groundwater Based on Helium Analyses}

\section{General Principles}

As water recharges an aquifer, the water that is in equilibrium with the atmosphere commonly is referred to as airsaturated water (ASW). The concentration of a dissolved gas in the water can be altered during recharge by the addition of more gas that is trapped by the recharging waters and forced into solution. This additional component greater than atmospheric solubility is referred to as "excess air" and typically has an air-like composition. Dissolved gas data, including isotopic composition, can be used to determine the amount of excess air measured in water. High concentrations of excess air are common in fractured-rock aquifers, in aquifers that function like fractured rock such as karst, and in aquifers in semiarid areas, such as the Edwards aquifer (Cook and others, 2006).

Most of the $\mathrm{He}$ in the atmosphere is ${ }^{4} \mathrm{He} ; \mathrm{R}_{\mathrm{A}}$ is $1.384 \mathrm{X}$ $10^{-6}$ (Clark and others, 1976; Clark and Fritz, 1997). Although local variation in He concentration (typical atmospheric concentration is 5.24 parts per million [Mamyrin and Tolstikhin, 1984]) and isotopic composition in the atmosphere might occur, the variation is presumed to be negligible. Concentrations of $\mathrm{He}$ in groundwater, much like other dissolved gases, initially conform to conditions of atmospheric solubility (recharge temperature, salinity [as indicated by dissolved solids concentration], and altitude) and excess air. Under typical recharge conditions, the atmospheric He component is about 50 to 100 microcubic centimeters per kilogram at standard temperature (20 degrees Celsius) and pressure ( 1 atmosphere $)^{1}$ $(\mu \mathrm{ccSTP} / \mathrm{kg})$. The solubility of He at 20 degrees Celsius in freshwater (the ASW value of $\mathrm{He}$ ) and 1,000 feet elevation is about $43.1 \mu \mathrm{ccSTP} / \mathrm{kg}$ (Weiss, 1971), and the isotopic composition is $0.98 \mathrm{R}_{\mathrm{A}}$ (Benson and Krause, 1980). These conditions represent the approximate mean annual air temperature and elevation of the study area, and they also are representative of recharge conditions.

Dissolved He in groundwater is derived from atmospheric and terrigenic (earth) sources. The atmospheric component includes air-soluble $\mathrm{He}$ and excess-air $\mathrm{He}$ (He derived from excess air) that results from dissolution of air bubbles trapped just below the water table. Another atmospheric source of $\mathrm{He}\left(\right.$ as ${ }^{3} \mathrm{He}$ ) is from decay of tritium in recent (less than 60 years old) recharged water; tritium concentrations in rainfall, some of which became recharge, during the mid-20th century were increased substantially by atmospheric testing of nuclear weapons (Michel, 1989).

Helium also can accumulate in groundwater in excess of the sum of ASW and excess-air concentrations because it is

\footnotetext{
${ }^{1}$ Standard conditions for temperature and pressure per U.S. Environmental Protection Agency (Electronic Code of Federal Regulations, 2009).
} 
produced by the radioactive decay of uranium and thorium in crustal rocks and aquifer solids (crustal $\mathrm{He}$ ) and from upward diffusion or advection of $\mathrm{He}$ from the mantle (mantle $\mathrm{He}$ ). Together, crustal and mantle $\mathrm{He}$ are termed terrigenic $\mathrm{He}$ (Solomon, 2000). Likely sources of terrigenic He in the study area include igneous rocks intruded into the Edwards aquifer, oil and gas hydrocarbons that are widely present in Edwards Group rocks downdip from the transition zone of the Edwards aquifer, rocks composing the underlying and adjacent Trinity aquifer, and rocks underlying the Trinity aquifer (fig. 2). Uranium concentrations from selected Edwards aquifer cores collected in the San Antonio area ranged from less than 0.1 to 1.7 milligrams per kilogram $(\mathrm{mg} / \mathrm{kg})$, and the median concentration was $0.6 \mathrm{mg} / \mathrm{kg}$ (K.M. Conko, U.S. Geological Survey, written commun., 2008), indicating that uranium concentrations in rocks of the Edwards aquifer typically might

\section{NORTHWEST}

\section{SOUTHEAST}

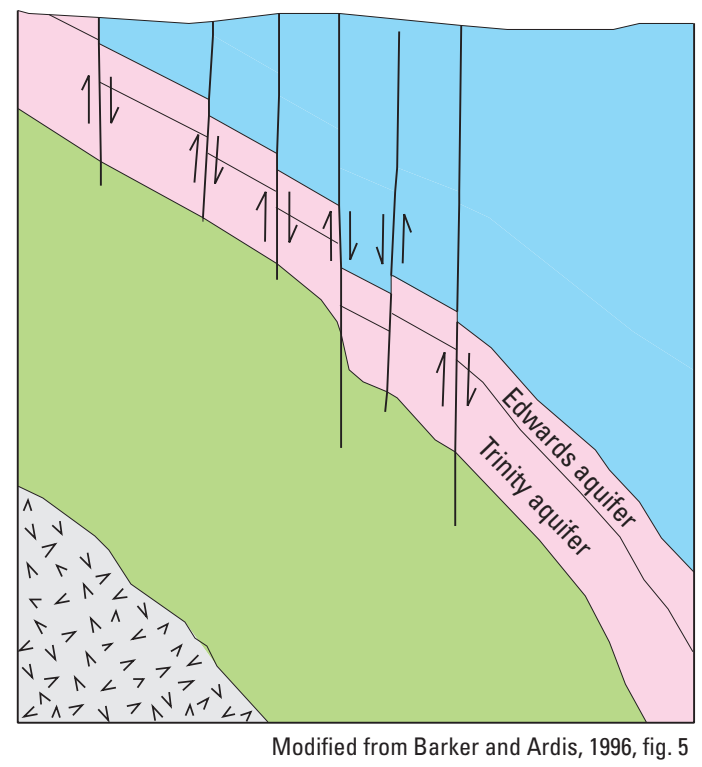

Not to scale

\section{EXPLANATION}

Cenozoic (mostly alluvium) and upper $C$ retaceous rocks ( $E$ dwards aquifer upper confining units)

L ower C retaceous rocks (E dwards and Trinity aquifers)

Paleozoic rocks

Precambrian rocks

Fault-A rrows show relative movement

Figure 2. Diagrammatic section showing generalized relation between the Edwards and Trinity aquifers and underlying preCretaceous rocks. be relatively low. The concentration of natural uranium in soil is about $2 \mathrm{mg} / \mathrm{kg}$ (International Atomic Energy Agency, 2009). Rocks of the Trinity aquifer generally contain more clastic material (conglomerate, sand, silt, clay, shale) than rocks of the Edwards aquifer (Duffin and Musick, 1991), and therefore might contain more radionuclide sources.

Except within active volcanic centers, terrigenic He is essentially all crustal $\mathrm{He}$. Crustal $\mathrm{He}$ has a ${ }^{3} \mathrm{He} /{ }^{4} \mathrm{He}$ isotopic ratio of $2.77 \times 10^{-8}$ (Mamyrin and Tolstikhin, 1984, p. 273); so as in atmospheric He, the dominant isotope by far in terrigenic He is ${ }^{4} \mathrm{He}$. Relatively high (greater than 1,000 $\mu \mathrm{ccSTP} /$ $\mathrm{kg}$ [Solomon, 2000]) terrigenic He concentrations typically are observed in older groundwater with residence times of thousands of years or more because of the relatively slow accumulation rate of crustal He. Terrigenic He concentrations in relatively old water can exceed the atmospheric component by several orders of magnitude (Davis and De Wiest, 1966; Marine, 1979; Stute and others, 1992).

\section{Helium Concentrations}

Because of the dominance of ${ }^{4} \mathrm{He}$ in atmospheric and terrigenic sources, helium results will pertain to ${ }^{4} \mathrm{He}$ unless otherwise noted. The concentration of ${ }^{4} \mathrm{He}$ in samples ranged from $63 \mu \mathrm{ccSTP} / \mathrm{kg}$ in well EU2 in the East Uvalde transect to $160,587 \mu \mathrm{ccSTP} / \mathrm{kg}$ in well KY3 in the Kyle transect (table 2). The lowest ${ }^{4} \mathrm{He}$ concentrations were measured in freshwater wells EU2 and KY1 and are more representative of atmospherically derived He. ${ }^{4} \mathrm{He}$ concentrations in the 10 saline wells generally increase from the western transects to the eastern transects, with the highest (and most variable) ${ }^{4} \mathrm{He}$ concentrations occurring in the Kyle transect. Increasing ${ }^{4} \mathrm{He}$ concentrations from southwest to northeast in the transition zone, indicating increasing residence time of groundwater from southwest to northeast, is consistent with the longstanding conceptualization of the Edwards aquifer: Water recharges in the southwest, flows generally northeasterly (including in the transition zone, although more slowly than in the freshwater zone), and discharges at major springs in the northeast (Lindgren and others, 2004).

In general, ${ }^{4} \mathrm{He}$ concentrations increase as salinity increases (fig. 3). Samples with the lowest salinities show typical ASW values of He coupled with some He from excess air. Because dissolved solids concentration was not measured in all samples, dissolved solids concentration was computed from a linear regression with specific conductance as follows: Dissolved solids $=0.658 \times$ specific conductance, with a coefficient of determination of 0.997 , which was determined from existing pairs of dissolved solids concentrations and specific conductance in table 2 . Assuming larger ${ }^{4} \mathrm{He}$ concentrations represent older water, the relation between ${ }^{4} \mathrm{He}$ and salinity indicates longer residence time for the more saline water. Water with longer residence time likely contains ${ }^{4} \mathrm{He}$ from crustal or mantle sources.

A relation between ${ }^{4} \mathrm{He}$ concentration and depth might contribute information useful for identifying sources of 


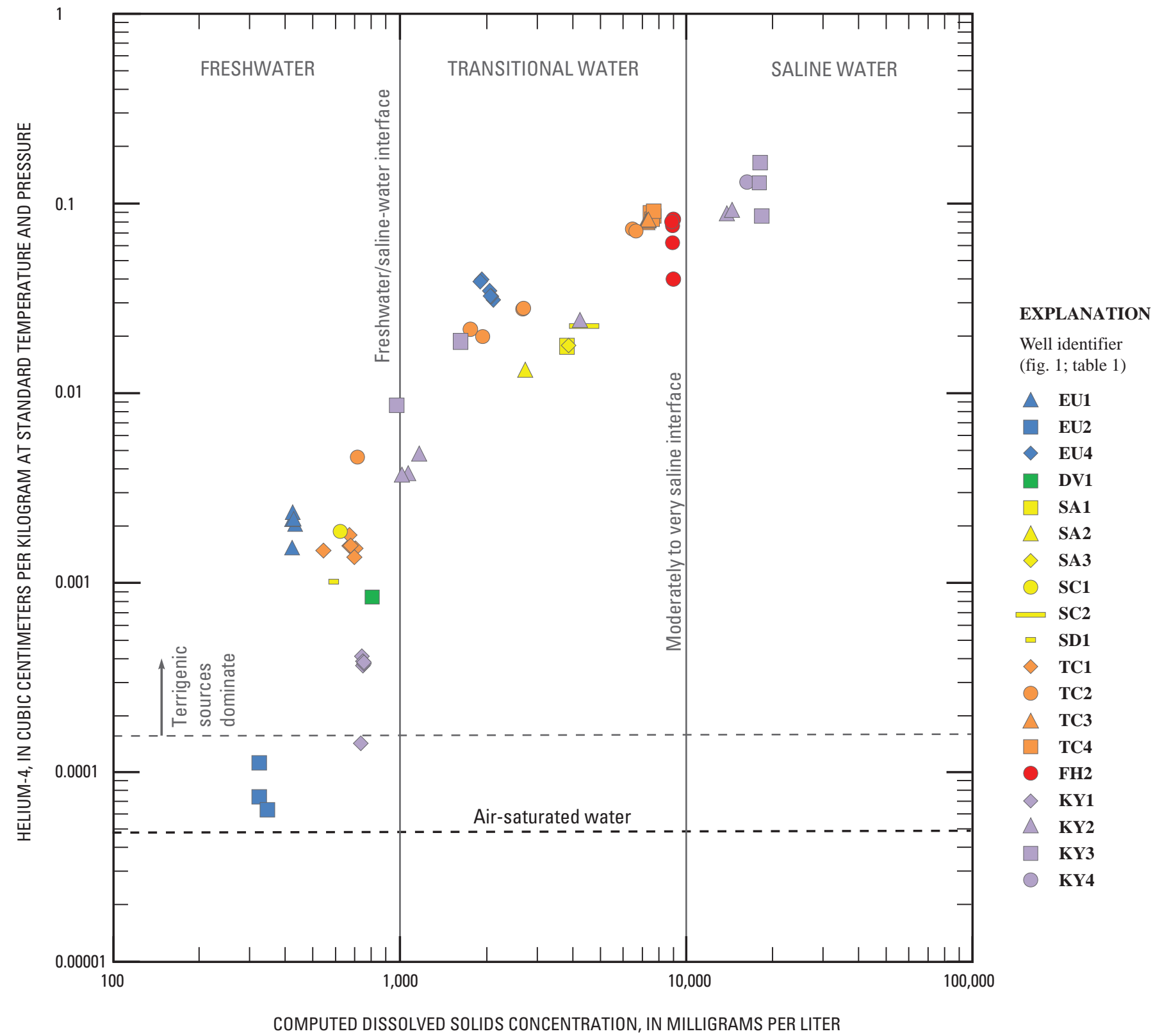

Figure 3. Relation of helium-4 concentration to salinity (computed dissolved solids concentration) in monitoring wells in and near the freshwater/saline-water transition zone of the San Antonio segment of the Edwards aquifer, south-central Texas, 2002-03.

${ }^{4} \mathrm{He}$ and thus sources of groundwater in the transition zone. However, no discernible relation is apparent (fig. 4). ${ }^{4} \mathrm{He}$ concentrations increase moderately with sample depth in TC2 and $\mathrm{KY}$, and slightly in $\mathrm{KY} 3$, but ${ }^{4} \mathrm{He}$ concentrations generally do not appear to increase with sample depth in most of the wells.

\section{Helium Isotopic Composition}

The presence and amount of excess ${ }^{4} \mathrm{He}\left({ }^{4} \mathrm{He}_{\mathrm{ex}}\right)$ can be useful for identifying possible sources of ${ }^{4} \mathrm{He}_{\mathrm{ex}}$. In this report, ${ }^{4} \mathrm{He}$ ex is computed as

$$
{ }^{4} \mathrm{He}_{\mathrm{ex}}={ }^{4} \mathrm{He}_{\text {measured }}-{ }^{4} \mathrm{He}_{\text {air-water equilibrium (ASW) }} \text {, }
$$

where

$$
{ }^{4} \mathrm{He}_{\mathrm{ASW}}=43.1 \mu \mathrm{ccSTP} / \mathrm{kg} \text {; }
$$

and the percentage of ${ }^{4} \mathrm{He}_{\mathrm{ex}}$ relative to ${ }^{4} \mathrm{He}$ in air at equilibrium with water $\left(\Delta^{4} \mathrm{He}_{\mathrm{ex}}\right)$ is computed as

$$
\Delta^{4} \mathrm{He}_{\mathrm{ex}}=\left({ }^{4} \mathrm{He}_{\mathrm{ex}} /{ }^{4} \mathrm{He} \mathrm{ASW}_{\mathrm{AW}}\right) \times 100 .
$$

When $\Delta^{4} \mathrm{He}_{\mathrm{ex}}$ is near zero, little excess air is present. When $\Delta^{4} \mathrm{He}_{\text {ex }}$ is greater than about 200 percent, excess $\Delta^{4} \mathrm{He}_{\text {ex }}$ from 


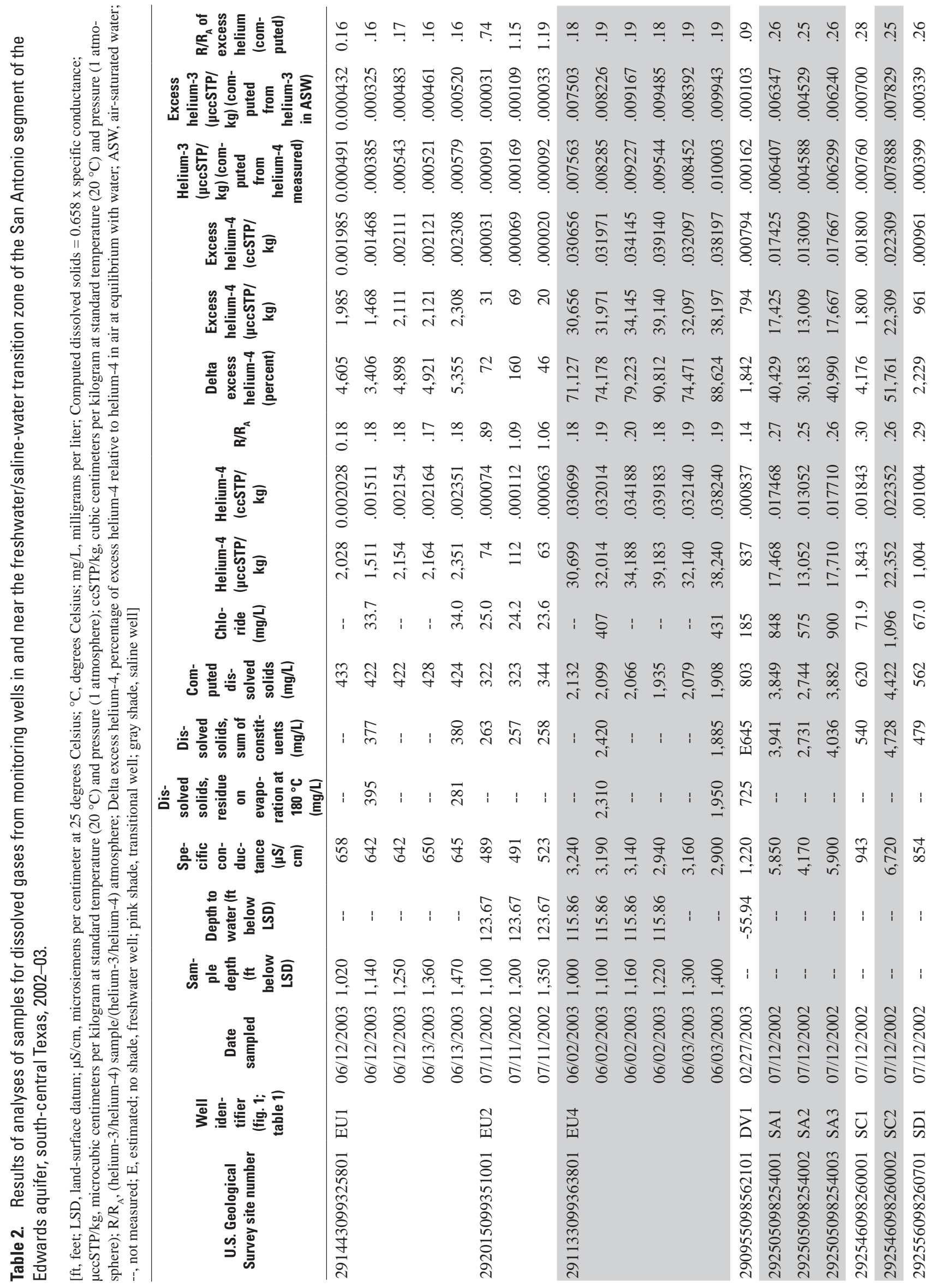




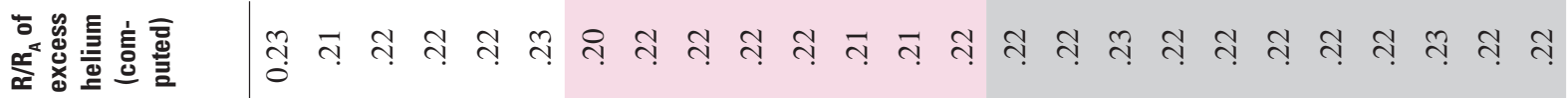

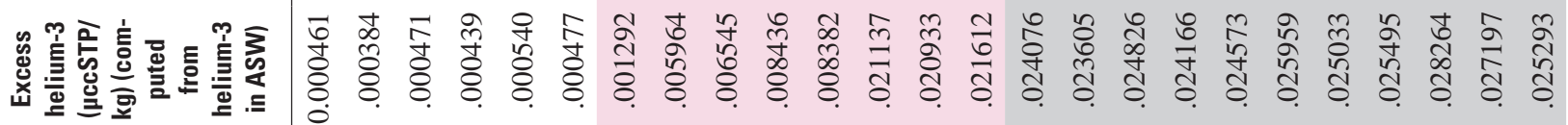

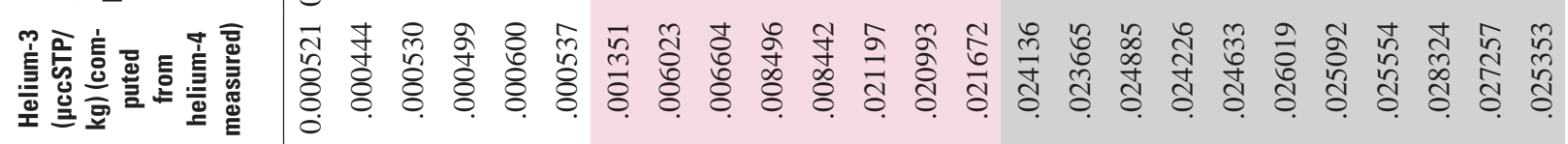

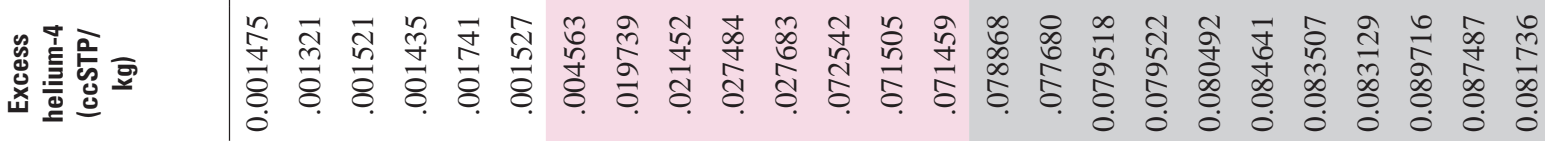

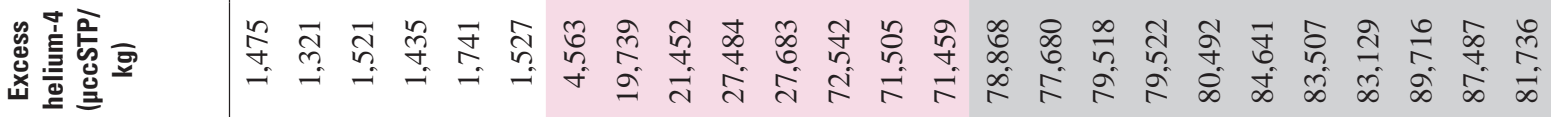

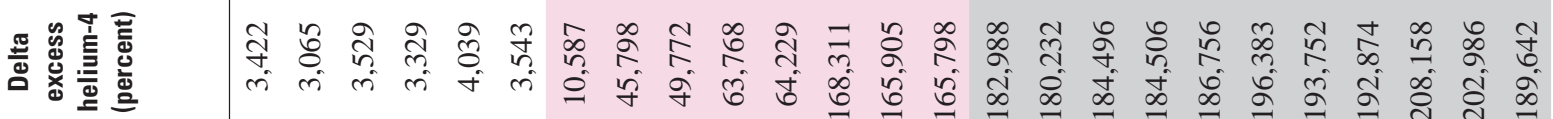

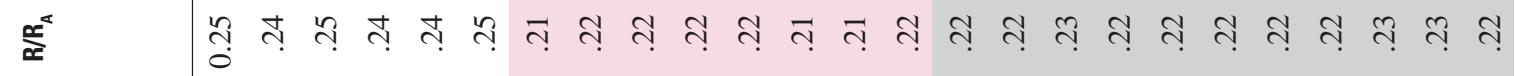

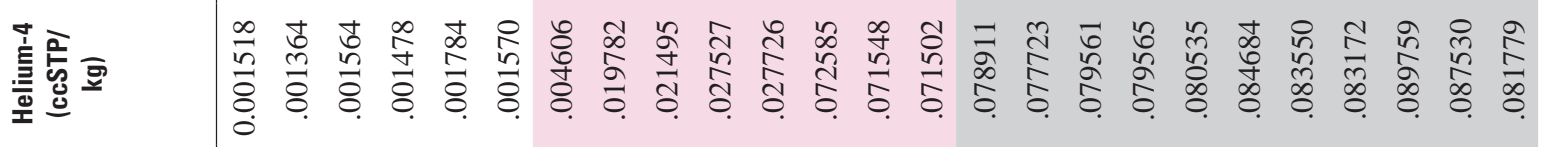

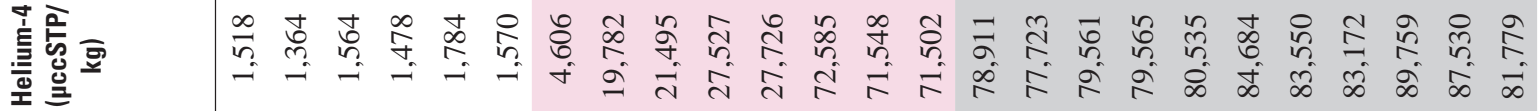

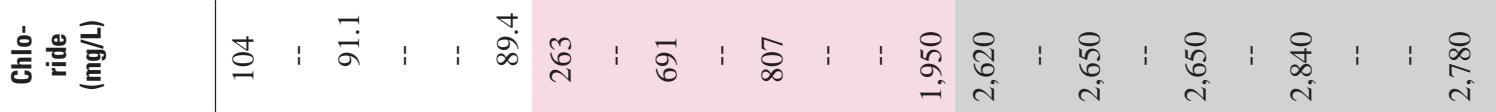

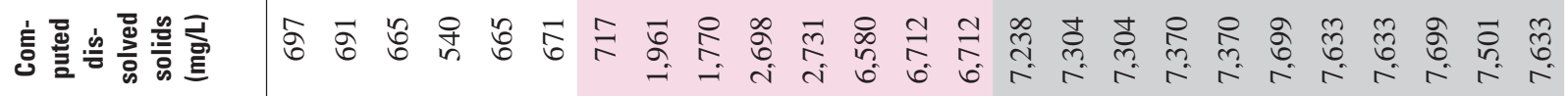

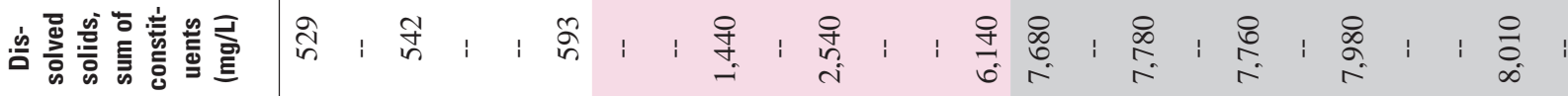

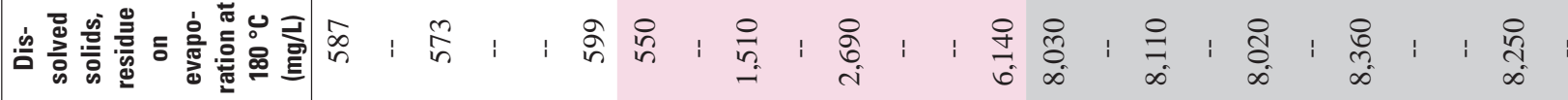

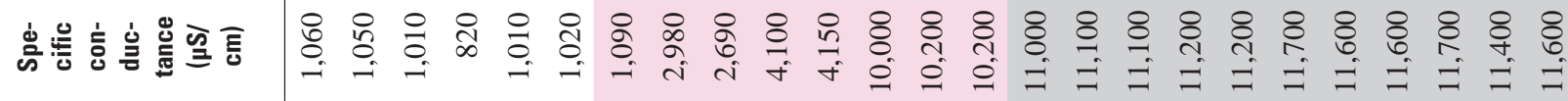

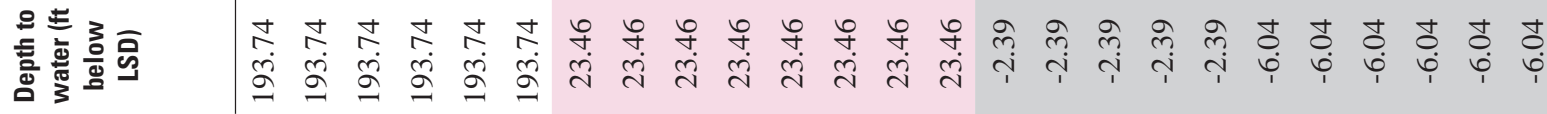

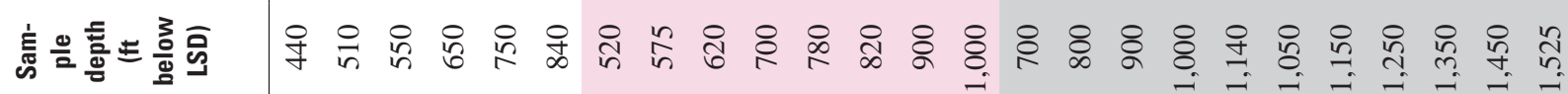




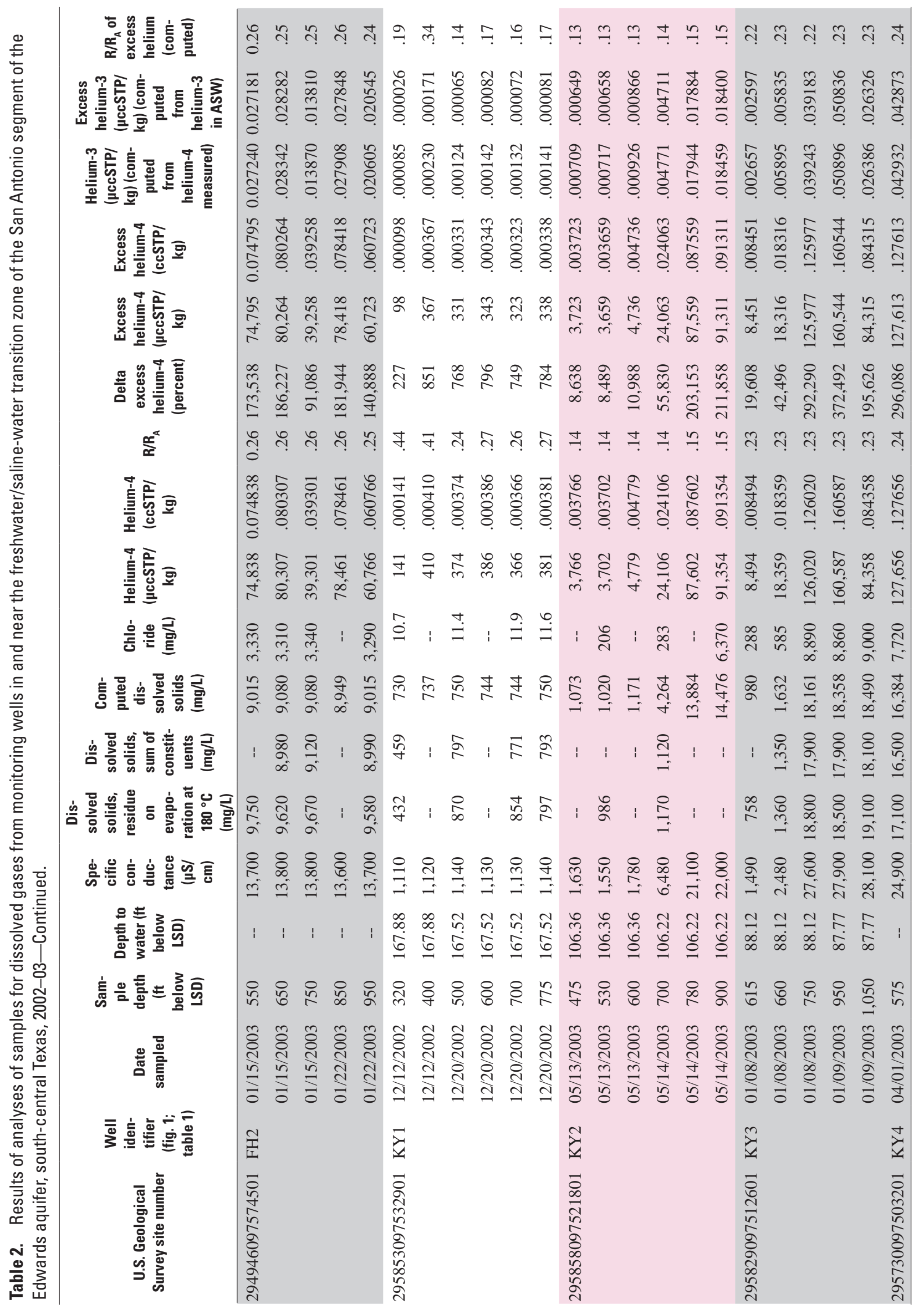




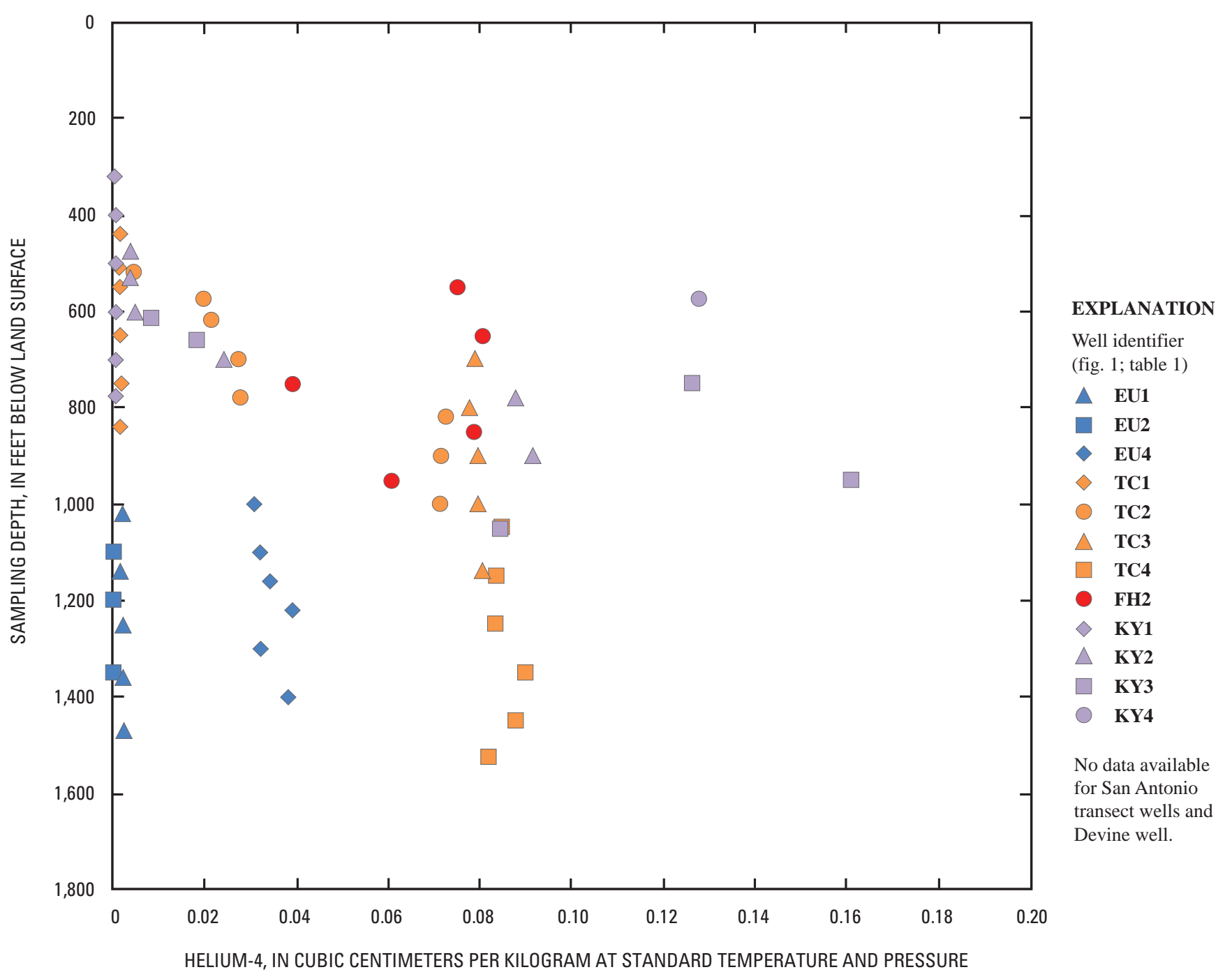

Figure 4. Relation of sampling depth to helium-4 concentration in monitoring wells in and near the freshwater/saline-water transition zone of the San Antonio segment of the Edwards aquifer, south-central Texas, 2002-03.

terrigenic sources dominates (L.N. Plummer, U.S. Geological Survey, written commun., 2009). $\Delta^{4} \mathrm{He}_{\mathrm{ex}}$ was greater than 1,000 percent for 60 of the 69 samples (table 2), indicating that terrigenic $\mathrm{He}$ is largely present. The nine samples with the lowest $\Delta^{4} \mathrm{He}_{\mathrm{ex}}$ values (from freshwater wells EU2 and KY1) likely contain mostly atmospherically derived ${ }^{4} \mathrm{He}$. The predominance of very large quantities of $\Delta^{4} \mathrm{He}_{\mathrm{ex}}$, much greater than could be derived from air-water equilibrium and excessair sources, indicates that groundwater residence times in the freshwater/saline-water transition zone are relatively long and that most of the $\Delta^{4} \mathrm{He}_{\mathrm{ex}}$ comes from sources other than the atmosphere.

Excluding three EU2 samples influenced by atmospheric sources $\left(\mathrm{R}=0.89 \mathrm{R}_{\mathrm{A}}, 1.09 \mathrm{R}_{\mathrm{A}}\right.$, and $1.06 \mathrm{R}_{\mathrm{A}}$ [table 2]), the mean isotopic composition for the remaining 66 samples is $0.22 \mathrm{R}_{\mathrm{A}}$. This relatively uniform isotopic composition might indicate a relatively homogeneous source of $\mathrm{He}$ in the fresh- water/saline-water transition zone. Homogeneous isotopic composition indicates a uniform source of ${ }^{4} \mathrm{He}_{\mathrm{ex}}$ consisting mostly of crustal ${ }^{4} \mathrm{He}$, where crustal $\mathrm{R}$ is about $0.02 \mathrm{R}_{\mathrm{A}}(2.77 \mathrm{x}$ $10^{-8}\left[\right.$ the ${ }^{3} \mathrm{He} /{ }^{4} \mathrm{He}$ ratio of crustal $\left.\mathrm{He}\right]$ and approximately equals 0.02 times $1.384 \times 10^{-6}\left[\right.$ the ${ }^{3} \mathrm{He} /{ }^{4} \mathrm{He}$ ratio of atmospheric $\left.\mathrm{He}\right]$ ) and possibly includes some mantle ${ }^{4} \mathrm{He}$, where $\mathrm{R}$ is about $8 \mathrm{R}_{\mathrm{A}}$ (Ozima and Podosek, 2002). Although some in situ production of He might occur in the Edwards aquifer, the Cretaceous carbonates are too young to have produced the large concentrations of ${ }^{4} \mathrm{He}$ observed. Mantle-derived igneous intrusions are present in and near the Edwards aquifer (Smith and others, 2002) and might be a source of mantle-derived ${ }^{4} \mathrm{He}$ (Hunt and others, 2005).

The mean $\mathrm{R}$ of the 32 samples from the 10 saline wells $\left(0.23 \mathrm{R}_{\mathrm{A}}\right.$, nearly the same as for the 66 wells noted in the previous paragraph) can be computed as a mixture of about 97 percent crustal ${ }^{4} \mathrm{He}$ (R equals about $0.02 \mathrm{R}_{\mathrm{A}}$ ) and 3 percent 
mantle (R equals about $8 \mathrm{R}_{\mathrm{A}}$ ), assuming the source of the ${ }^{4} \mathrm{He}$ is entirely terrigenic. The source of ${ }^{4} \mathrm{He}$ to the saline water could be migration from deep crustal rocks (fig. 2), by way of faults or fractures, or rocks nearer the Edwards aquifer that contain or radiogenically produce $\mathrm{He}$. Other noble gas ( $\mathrm{Ne}, \mathrm{Ar}$ ) data (Lambert and others, 2009) indicate oil and gas hydrocarbons, which are present in relatively deep Edwards Group rocks, are a potential source of ${ }^{4} \mathrm{He}_{\mathrm{ex}}$. Those data indicate that there are fractionation pathways (models) between ASW and fluids of varying composition representative of hydrocarbon-bearing rocks (A.G. Hunt, U.S. Geological Survey, written commun.,
2009). No noble gas data were collected from the Trinity aquifer for this report, so that potential source could not be evaluated directly. Although Groschen and Buszka (1997) did not identify updip movement of saline water from relatively deep Edwards Group rocks to the shallower transition zone of the Edwards aquifer, a recent study (MaryLynn Musgrove, U.S. Geological Survey, written commun., 2009) indicates that, in localized areas, saline water is mixed with freshwater; and that the likely sources of saline water are relatively deep Edwards Group rocks, or the Trinity aquifer, or both.

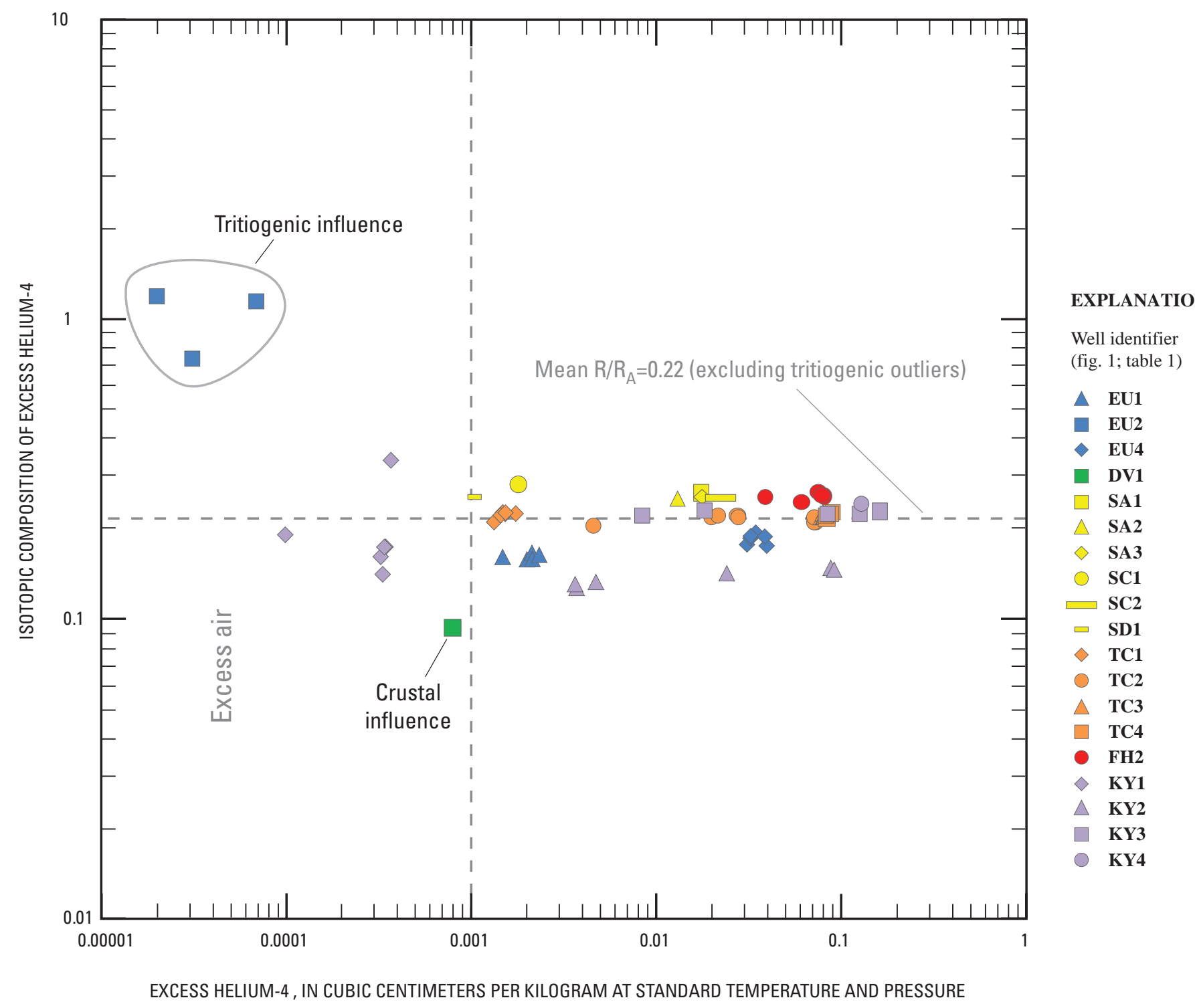

Figure 5. Relation of isotopic composition of excess helium-4 $\left(\mathrm{R} / \mathrm{R}_{\mathrm{A}}{ }^{4} \mathrm{He}{ }_{\mathrm{ex}}\right)$ to excess helium-4 $\left({ }^{4} \mathrm{He}_{\mathrm{ex}}\right)$ concentration in monitoring wells in and near the freshwater/saline-water transition zone of the San Antonio segment of the Edwards aquifer, south-central Texas, 2002-03. 
A graph of $\mathrm{R} / \mathrm{R}_{\mathrm{A}}$ of ${ }^{4} \mathrm{He}_{\mathrm{ex}}\left(\mathrm{R}^{4} \mathrm{He}_{\mathrm{ex}} / \mathrm{R}_{\mathrm{A}}\right)$ relative to the concentration of ${ }^{4} \mathrm{He}$ in samples from all wells (fig. 5) might indicate sources of ${ }^{4} \mathrm{He}_{\mathrm{ex}} \cdot \mathrm{R}^{4} \mathrm{He}_{\mathrm{ex}} / \mathrm{R}_{\mathrm{A}}$ is computed as

$$
\mathrm{R}^{4} \mathrm{He}_{\mathrm{ex}} / \mathrm{R}_{\mathrm{A}}=\left({ }^{3} \mathrm{He}_{\mathrm{ex}} /{ }^{4} \mathrm{He}_{\mathrm{ex}}\right) / 1.384 \times 10^{-6},
$$

where ${ }^{3} \mathrm{He}_{\text {ex }}$ is computed as

$$
{ }^{3} \mathrm{He}_{\mathrm{ex}}={ }^{3} \mathrm{He}-{ }^{3} \mathrm{He}_{\mathrm{ASW}} .
$$

${ }^{3} \mathrm{He}$ in the equation immediately above is computed from $\mathrm{R} / \mathrm{R}_{\mathrm{A}}$ and ${ }^{4} \mathrm{He}$ (table 2), and ${ }^{3} \mathrm{He} \mathrm{ASw}_{\text {is }}$ is computed as 43.1 $\mu \mathrm{ccSTP} / \mathrm{kg} \times 1.384 \times 10^{-6}$. Excluding five outliers, the $\mathrm{R}^{4} \mathrm{He}_{\mathrm{ex}} /$ $R_{A}$ values for all samples are between 0.1 and 0.3 for all values of ${ }^{4} \mathrm{He}_{\text {ex }}$. Whether the variation in that range among transects or wells within transects is meaningful relative to sources of $\mathrm{He}$ is unknown. However, because the ${ }^{4} \mathrm{He}$ concentration in all but the freshest samples is almost entirely excess ${ }^{4} \mathrm{He}_{\mathrm{ex}}, \mathrm{R} /$ $\mathrm{R}_{\mathrm{A}}$ of ${ }^{4} \mathrm{He}_{\text {ex }}$ is about equal to $\mathrm{R} / \mathrm{R}_{\mathrm{A}}$ of ${ }^{4} \mathrm{He}$. As previously noted in this section, relatively uniform isotopic composition might indicate a relatively homogeneous source of $\mathrm{He}$ in the freshwater/saline-water transition zone.

As for the outliers, two outliers have $\mathrm{R}^{4} \mathrm{He}_{\text {ex }}$ values greater than $R_{A}\left(E U 2, R / R_{A}\right.$ greater than 1$)$, indicating that ${ }^{3} \mathrm{He}$ dominates the composition; ${ }^{3} \mathrm{He}$ comes from radiogenic decay of tritium in recently recharged water. Two other outliers have $\mathrm{R}^{4} \mathrm{He}_{\mathrm{ex}}$ values of $0.74 \mathrm{R}_{\mathrm{A}}$ and $0.34 \mathrm{R}_{\mathrm{A}}$ (EU2 and KY1, respectively). These two samples likely are mixtures containing $\mathrm{He}$ from recently recharged water and from crustal sources. The fifth outlier, DV1 $\left(\mathrm{R}^{4} \mathrm{He}_{\mathrm{ex}}=0.09 \mathrm{R}_{\mathrm{A}}\right)$, is the lowest value, strongly reflecting the dominance of the crustal component of ${ }^{4} \mathrm{He}_{\mathrm{ex}}$ in the sample.

The He data of this report are problematic in that they cannot be used to identify sources of groundwater in and near the transition zone of the Edwards aquifer in terms of specific geologic (stratigraphic) units or hydrogeologic units (aquifers or confining units). However, the data indicate that the source or sources of the He, and thus the water in which it is dissolved, in the transition zone are mostly terrigenic in origin rather than atmospheric, and that the dominant terrigenic source likely is crustal rocks rather than deeper mantle rocks. As previously noted in this section, likely sources of crustal $\mathrm{He}$ are oil and gas hydrocarbons that are widely present in Edwards Group rocks downdip from the transition zone of the Edwards aquifer, and potentially rocks composing the underlying and adjacent Trinity aquifer. Whether most He in and near the transition zone of the Edwards aquifer originated either in rocks outside the transition zone and at depth or in the adjacent Trinity aquifer is uncertain; but most of the He in the transition zone had to enter the transition zone from the Trinity aquifer because the Trinity aquifer is the hydrogeologic unit immediately beneath and laterally adjacent to the transition zone of the Edwards aquifer. Thus the He data support a hypothesis of sufficient hydraulic connection between the Trinity and Edwards aquifers to allow movement of water from the Trinity aquifer to the transition zone of the Edwards aquifer.

\section{Summary}

This report evaluates dissolved noble gas data, specifically helium-3 $\left({ }^{3} \mathrm{He}\right)$ and helium-4 $\left({ }^{4} \mathrm{He}\right)$, collected by the U.S. Geological Survey during 2002-03 as part of a larger, 9-year study of the freshwater/saline-water transition zone of the Edwards aquifer done by the U.S. Geological Survey in cooperation with the San Antonio Water System. Helium analyses are used to provide insight into the sources of water in the transition zone. Sixty-nine dissolved gas samples were collected from 19 monitoring wells (categorized as fresh, transitional, or saline on the basis of dissolved solids concentration in samples from the wells or from fluid-profile logging of the boreholes) arranged in five transects, except for the Devine well in Medina County, across the freshwater/salinewater interface (the 1,000-mg/L dissolved solids concentration threshold) of the Edwards aquifer.

Dissolved helium in groundwater is derived from atmospheric and terrigenic (earth) sources. The concentration of helium-4 (the dominant isotope in atmospheric and terrigenic helium) in samples ranged from $63 \mu \mathrm{ccSTP} / \mathrm{kg}$ in well EU2 in the East Uvalde transect to $160,587 \mu \mathrm{ccSTP} / \mathrm{kg}$ in well KY3 in the Kyle transect. Helium-4 concentrations in the 10 saline wells generally increase from the western transects to the eastern transects, with the highest (and most variable) helium-4 concentrations occurring in the Kyle transect. Increasing helium-4 concentrations from southwest to northeast in the transition zone, indicating increasing residence time of groundwater from southwest to northeast, is consistent with the longstanding conceptualization of the Edwards aquifer: Water recharges in the southwest, flows generally northeasterly (including in the transition zone, although more slowly than in the freshwater zone), and discharges at major springs in the northeast.

When excess helium-4 (the percentage of excess helium-4 [difference between measured helium- 4 concentration and helium-4 concentration in air-saturated water]) is greater than about 200 percent, excess helium-4 from terrigenic sources dominates. Excess helium-4 was greater than 1,000 percent for 60 of the 69 samples, indicating that terrigenic helium is largely present and that most of the excess helium-4 comes from sources other than the atmosphere.

The ratio of ${ }^{3} \mathrm{He} /{ }^{4} \mathrm{He}$ in a sample (R), the isotopic composition, is commonly expressed as a multiple of the ratio of ${ }^{3} \mathrm{He} /{ }^{4} \mathrm{He}$ in the atmosphere (in air) $\left(\mathrm{R}_{\mathrm{A}}\right)$. The mean $\mathrm{R}$ of the 32 samples from the 10 saline wells $\left(0.23 \mathrm{R}_{\mathrm{A}}\right)$ can be computed as a mixture of about 97-percent crustal helium-4 ( $R$ equals about $0.02 \mathrm{R}_{\mathrm{A}}$ ) and 3-percent mantle ( $\mathrm{R}$ equals about 8 $R_{A}$ ), assuming the source of the helium- 4 is entirely terrigenic. The source of helium- 4 to the saline water could be deep crustal rocks, by way of faults or fractures, or rocks nearer the Edwards aquifer that contain or radiogenically produce helium.

The helium data of this report cannot be used to identify sources of groundwater in and near the transition zone of the Edwards aquifer in terms of specific geologic (stratigraphic) 
units or hydrogeologic units (aquifers or confining units). However, the data indicate that the source or sources of the helium, and thus the water in which the helium is dissolved, in the transition zone are mostly terrigenic in origin rather than atmospheric, and that the dominant terrigenic source likely is crustal rocks rather than deeper mantle rocks. Likely sources of crustal helium are oil and gas hydrocarbons that are widely present in Edwards Group rocks downdip from the transition zone of the Edwards aquifer, and potentially rocks composing the underlying and adjacent Trinity aquifer. Whether most helium in and near the transition zone of the Edwards aquifer originated either in rocks outside the transition zone and at depth or in the adjacent Trinity aquifer is uncertain; but most of the helium in the transition zone had to enter the transition zone from the Trinity aquifer because the Trinity aquifer is the hydrogeologic unit immediately beneath and laterally adjacent to the transition zone of the Edwards aquifer. Thus the helium data support a hypothesis of sufficient hydraulic connection between the Trinity and Edwards aquifers to allow movement of water from the Trinity aquifer to the transition zone of the Edwards aquifer.

\section{References Cited}

Ashworth, J.B., and Hopkins, Janie, 1995, Major and minor aquifers of Texas: Texas Water Development Board Report $345,65 \mathrm{p}$.

Barker, R.A., and Ardis, A.F., 1996, Hydrogeologic framework of the Edwards-Trinity aquifer system, west-central Texas, in Regional Aquifer-System Analysis-EdwardsTrinity aquifer system: U.S. Geological Survey Professional Paper 1421-B, 61 p., 8 pl.

Bayer, R., Schlosser, P., Bonisch, G., Rupp, H., Zaucker, F., and Zimmek, G., 1989, Performance and blank components of a mass spectrometric system routine measurement of helium isotopes and tritium by ${ }^{3} \mathrm{He}$ ingrowth method: Heidelberg, Springer Verland, Sitzungsberichte der Heidelberger Akademie der Wissenschaften, MathematischNaturwissenschaftliche Klasse, p. 241-279.

Benson, B.B., and Krause, D.J., 1980, Isotope fractionation of helium solution-A probe for the liquid state: Journal of Solution Chemistry, v. 9, p. 895-909.

Clark, I.D., and Fritz, Peter, 1997, Environmental isotopes in hydrogeology: Boca Raton, Fla., Lewis Publishers, 296 p.

Clarke, W.B., Jenkins, W.J., and Top, Z., 1976, Determination of tritium by mass spectrometric measurement of ${ }^{3} \mathrm{He}$ : International Journal of Applied Radiation and Isotopes, v. 27 , no. 9 , p. 515-522.

Cook, P.G., Plummer, L.N., Solomon, D.K., Busenberg, E., and Han, L.F., 2006, Chapter 4-Effects and processes that can modify apparent CFC age, in Use of chlorofluorocar- bons in hydrology, a guidebook: Vienna, Austria, International Atomic Energy Agency, p. 31-58.

Davis, S.N., and De Wiest, R.J.M., 1966, Hydrogeology: New York, John Wiley, 463 p.

Duffin, Gail, and Musick, S.P., 1991, Evaluation of water resources in Bell, Burnet, Travis, Williamson and parts of adjacent counties, Texas: Texas Water Development Board Report 326, 105 p.

Electronic Code of Federal Regulations, 2009, Title 40-Protection of environment, part 60 - Standards of performance for new sources, subpart A-General provisions: accessed September 30, 2009, at http://ecfr.gpoaccess.gov/cgi/t/text/ text-idx? c =ecfr\&sid $=1$ fab1f8b97ed038882 ce6f28eaf948 $19 \&$ rgn $=$ div $8 \&$ view $=$ text $\&$ node $=40: 6 \cdot 0 \cdot 1 \cdot 1 \cdot 1 \cdot 1 \cdot 133.2 \& i$ dno $=40$.

Groschen, G.E., and Buszka, P.M., 1997, Hydrogeologic framework and geochemistry of the Edwards aquifer salinewater zone, south-central Texas: U.S. Geological Survey Water-Resources Investigations Report 97-4133, 47 p.

Hunt, A.G., Landis, G.P., and Lambert, R.B., 2005, Noble gas geochemistry of the freshwater/saline-water transition zone of the Edwards aquifer-Implications for ground-water flow and mixing: Geological Society of America Abstracts with Programs, v. 37, no. 7, p. 217.

International Atomic Energy Agency, 2009, Depleted uranium: accessed December 8, 2009, at http://www.iaea.org/ NewsCenter/Features/DU/du_qaa.shtml.

Lambert, R.B., Hunt, A.G., Stanton, G.P., and Nyman, M.B., 2009, Water-level, borehole geophysical log, and waterquality data from wells transecting the freshwater/salinewater interface of the San Antonio segment of the Edwards aquifer, south-central Texas, 1999-2007: U.S. Geological Survey Data Series 403 [variously paged].

Lindgren, R.J., Dutton, A.R., Hovorka, S.D., Worthington, S.R.H., and Painter, Scott, 2004, Conceptualization and simulation of the Edwards aquifer, San Antonio region, Texas: U.S. Geological Survey Scientific Investigations Report 2004-5277, 143 p., 7 pl.

Maclay, R.W., 1995, Geology and hydrology of the Edwards aquifer in the San Antonio area, Texas: U.S. Geological Survey Water-Resources Investigations Report 95-4186, $64 \mathrm{p}$.

Mamyrin, B.A., and Tolstikhin, I.N., 1984, Helium isotopes in nature-Developments in geochemistry, v. 3: New York, Elsevier, $273 \mathrm{p}$.

Marine, I.W., 1979, The use of naturally occurring helium to estimate groundwater velocities for studies of geological storage of radioactive waste: Water Resources Research, v. 15 , p. $1,130-1,136$. 
Michel, R.L., 1989, Tritium deposition over the continental United States, 1953-1983, in Atmospheric deposition, International Association of Hydrological Sciences symposium, Baltimore, Maryland, May 11-12, 1989, Proceedings: United Kingdom, International Association of Hydrological Sciences Publication 179, p. 109-115.

Ozima, Minoru, and Podosek, F.A., 2002, Noble gas geochemistry: New York, Cambridge University Press, 281 p.

Pavlicek, Dianne, Small, T.A., and Rettman, P.L., 1987, Hydrogeologic data from a study of the freshwater zone/ salinewater zone interface in the Edwards aquifer, San Antonio region, Texas: U.S. Geological Survey Open-File Report 87-389, 108 p.

Poteet, Diane, Collier, Hughbert, and Maclay, R.W., 1992, Investigation of the fresh/saline-water interface in the Edwards aquifer in New Braunfels and San Marcos, Texas: San Antonio, Edwards Underground Water District Report 92-02, $171 \mathrm{p}$.

Schultz, A.L., 1994, Review and update of the position of the Edwards aquifer freshwater/saline-water interface from Uvalde to Kyle, Texas: San Antonio, Edwards Underground Water District Report 94-05, 31 p.

Smith, D.V., Smith, B.D., and Hill, P.L., 2002, Aeromagnetic survey of Medina and Uvalde Counties: U.S. Geological Survey Open-File Report 02-049 [variously paged].

Solomon, D.K., 2000, ${ }^{4} \mathrm{He}$ in groundwater, in Cook, P.G., and Herczeg, A.L., eds., Environmental tracers in subsurface hydrology: New York, Kluwer Academic Publishers, p. 425-439.

Solomon, D.K., Hunt, A., and Poreda, R.J., 1996, Source of radiogenic helium 4 in shallow aquifers-Implications for dating young groundwater: Water Resources Research, v. 32 , no. 6 , p. $1,805-1,813$.

Solomon, D.K., Poreda, R.J., Cook, P.G., and Hunt, A.G., 1995, Site characterization using ${ }^{3} \mathrm{H} /{ }^{3} \mathrm{He}$ ground-water ages, Cape Cod, Massachusetts: Ground Water, v. 33, no. 6, p. 988-996.

Stute, M., Sonntag, C., Deák, J., and Schlosser, P., 1992, Helium in deep circulating groundwater in the Great Hungarian Plain-Flow dynamics and crustal and mantle helium fluxes: Geochimica et Cosmochimica Acta, v. 56, no. 5, p. 2,051-2,067.

U.S. Census Bureau, 2010, State \& county quickfacts-Texas: accessed February 16, 2010, at http://quickfacts.census.gov/ qfd/states/48000.html.

Weast, R.C., ed., 1983, CRC Handbook of chemistry and physics (63d ed.): Boca Raton, Fla., CRC Press.

Weiss, R.F., 1971, Solubility of helium and neon in water and seawater: Journal of Chemical and Engineering Data, v. 16, no. 2, p. 235-240.

Winslow, A.G., and Kister, L.R., 1956, Saline-water resources of Texas: U.S. Geological Survey Water-Supply Paper 1365, $105 \mathrm{p}$. 
